\title{
Survival probability of immature green turtles in two foraging grounds at Culebra, Puerto Rico
}

\author{
Ana R. Patrício ${ }^{1, *}$, Ximena Velez-Zuazo ${ }^{1,2}$, Carlos E. Diez ${ }^{3}$, Robert Van Dam ${ }^{4}$, \\ Alberto M. Sabat ${ }^{1}$ \\ ${ }^{1}$ Department of Biology, University of Puerto Rico, Rio Piedras campus, PO Box 23360, San Juan, PR 00931, Puerto Rico \\ 2 ecOceanica, Lima 41, Peru \\ ${ }^{3}$ Programa de Especies Protegidas, DRNA-PR, San Juan, PR 00936, Puerto Rico \\ ${ }^{4}$ Chelonia Inc., PO Box 9020708, San Juan, PR 00902-0708, Puerto Rico
}

\begin{abstract}
Inshore bays are key foraging grounds for immature green turtles Chelonia mydas. At these confined areas, capture-mark-recapture (CMR) programs generate valuable information that can be used to estimate vital rates, essential for the effective conservation of this endangered species. We compiled the CMR history profiles of 273 individuals from $13 \mathrm{yr}$ of in-water surveys and employed the Cormack-Jolly-Seber model to estimate the survival probabilities of green turtles in 2 neritic bays at Culebra municipality, Puerto Rico. The CMR profiles were grouped into 2 size classes: juvenile and subadult. No adults were captured during the study. We found no significant differences in survival probability between the green turtles occupying each bay. We also assessed the survival probability of fibropapillomatosis (FP)-afflicted turtles versus FP-free turtles and found no significant differences among these groups. However, there was a significant difference in survival between the 2 size classes. Juveniles showed a higher survival probability $(0.8322,95 \% \mathrm{CI}=0.7875$ to 0.8690$)$ than subadults $(0.5290,95 \% \mathrm{CI}=0.3851$ to 0.6682$)$. The low survival of subadults is potentially biased by the permanent emigration of some of these individuals. Previous studies have shown that larger immatures leave shallow protected bays and occupy deeper open waters, sometimes associated with adults. Juveniles seem to be resident, and their survival rate can serve as a reference value for viability analysis. This is the first study on the survival of green turtles in the West Indies.
\end{abstract}

KEY WORDS: Survival probability · Chelonia mydas · Cormack-Jolly-Seber · Capture-markrecapture study $\cdot$ Fibropapillomatosis

\section{INTRODUCTION}

The degradation of habitats and human exploitation have been causing the decline of many species worldwide. For large marine vertebrates, overfishing has been the main reason for population decreases (Jackson et al. 2001, Lewison et al. 2004, Soykan et al. 2008). As a result, various groups of species, including tuna, sharks, billfishes, whales, and sea turtles, are in urgent need of conservation efforts (Powles et al. 2000, Baum et al. 2003, Fromentin \&
Powers 2005, Chaloupka \& Balazs 2007). In addition, for migratory marine animals that occupy coastal regions during certain stages of their life cycle, the continuous degradation of the shoreline potentiates the risk of population extinction (Carr et al. 1978, Castro 1993, Gillanders et al. 2003, Lotze et al. 2006). One important approach to determine actions for the effective conservation of endangered species is to investigate their population dynamics and demography (Crouse et al. 1987, Fujiwara \& Caswell 2002, Monticelli et al. 2010). Mark-recapture estimates of 
survival probability have been widely employed in animal population studies (Lebreton et al. 1992, Pradel et al. 1997, Bjorndal et al. 2003b, Campbell \& Lagueux 2005, Monticelli et al. 2010) and have become an important means for application in longterm population management (Fujiwara \& Caswell 2002).

The survival probability of sea turtles has been investigated by the analysis of capture-markrecapture (CMR) data, mostly of live captures (Chaloupka \& Limpus 2002, Chaloupka \& Limpus 2005, Eguchi et al. 2010). Recent studies have shown the need for high survival rates in the large juvenile, subadult, and adult stages for a positive or stable long-term population growth (Heppell 1998, Crouse 1999, Heppell et al. 2003). One holdback of models that only include data from live captures, such as the Cormack-Jolly-Seber (CJS; Lebreton et al. 1992), is the inability to distinguish between permanent emigration and death (Heppell 1998, White \& Burnham 1999). Extensions to the CJS model, such as the Burnham (1993) and the Barker (1997) models, can incorporate data from tag recoveries (i.e. from animals found dead) or from both tag return and resight occasions, in the latter case improving the model capacity and allowing estimations of true survival and emigration rates. However, dead recoveries of marked individuals are often too sparse to include in the models (Bjorndal et al. 2003a).

The green turtle is listed as endangered by the International Union for the Conservation of Nature (IUCN 2010). Over the past 3 decades, the major green turtle nesting populations have increased worldwide (Chaloupka \& Balazs 2007, Chaloupka et al. 2008). Yet the combination of human exploitation, habitat destruction (Chaloupka et al. 2008), by-catch (Epperly et al. 2007, Varghese et al. 2010), and emerging diseases, such as the debilitating tumor disease fibropapillomatosis (FP; Herbst et al. 2004), have led to the critical decline of some stocks.

The life history of the green turtle is marked by ontogenic habitat shifts and large-scale migrations (Heppell et al. 2003, Arthur 2008). After hatching at the beach, green turtles undertake an oceanic period associated with a pelagic life style, which in the Greater Caribbean may last ca. 3 yr (Bjorndal et al. 2005). At 20 to $35 \mathrm{~cm}$ of curved carapace length (CCL), they recruit to neritic foraging grounds and shift into benthic feeding (Bolten 2003), mostly on seagrasses in the Caribbean (Bjorndal 1997). Neritic zones are used as developmental habitats, and turtles may spend decades foraging in these areas until reaching sexual maturity (Bjorndal et al. 2005). Upon reaching maturity, they make periodic migrations between their natal rookeries and neritic bays (Carr et al. 1978, Chaloupka et al. 2004, Bowen \& Karl 2007). Neritic areas may be occupied by green turtles at life stages ranging from small immatures, to larger immatures and adults (Bolten 2003, Koch et al. 2007).

In Puerto Rico, the most studied foraging grounds for green turtles are Puerto Manglar and Tortuga Bay (Diez et al. 2010). Small green turtles (24 cm CCL) have been observed recruiting to these coastal bays, where they appear to forage for several years and leave before the onset of sexual maturity. Since 2001, turtles with FP were reported at Puerto Manglar, with high to medium prevalence, i.e. $57 \%$ from 2001 to 2005 and $30 \%$ between 2006 and 2007 (Diez et al. 2010). At Tortuga Bay, FP was rare until June 2009, when $40 \%$ of the turtles captured there presented fibropapillomas. Mitochondrial DNA analysis has shown that Tortuga Bay and Puerto Manglar green turtle aggregations come from multiple rookeries (Velez-Zuazo et al. 2010) belonging to all 5 Atlantic and Caribbean Regional Management Units identified by Wallace et al. (2010). In this study, we investigated the size-class-specific survival probabilities of green turtles foraging in Puerto Manglar and Tortuga Bay, and make inferences concerning the dynamics of these aggregations. In addition, we explored the potential influence of FP on the survival rate.

\section{MATERIALS AND METHODS}

\section{Study site}

The coastal area around Culebra and its satellite islands, east of the main island of Puerto Rico, is a critical habitat for green turtles, as designated by the Endangered Species Act 1998. Our data set is from 2 foraging grounds inside the boundaries of the green turtle critical habitat: Puerto Manglar and Tortuga Bay (Fig. 1). Puerto Manglar $\left(18.30^{\circ} \mathrm{N}, 65.25^{\circ} \mathrm{W}\right)$ is a mangrove bay surrounded by wetlands, residential development, and roads, located at the southeast coast of Culebra island. Red mangroves Rhizophora mangle border the inner shores, and most of the submerged area is occupied by aquatic vegetation, dominated by Thalassia testudinum and macroalgae (Diez et al. 2010). The area most utilized by green turtles for foraging is 1 to $5 \mathrm{~m}$ in depth, and the water typically has high turbidity. Tortuga Bay $\left(18.22^{\circ} \mathrm{N}, 65.22^{\circ} \mathrm{W}\right)$ is located on the uninhabited island of Culebrita and is managed by the U.S. Fish and Wildlife Service as part of the Culebra National Wildlife Refuge. The bay 


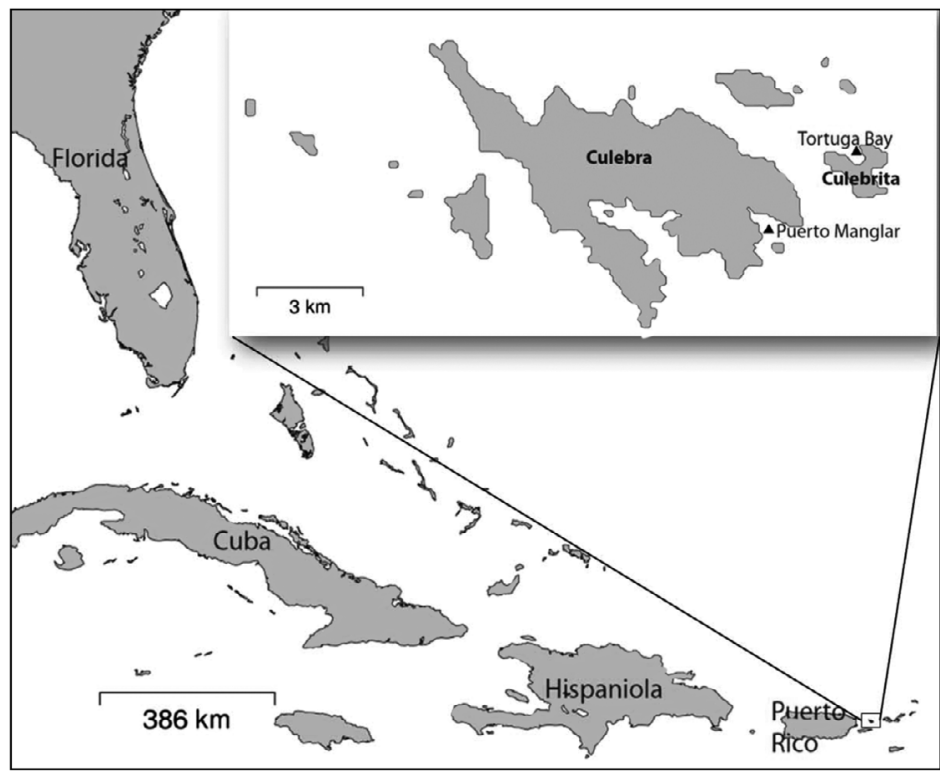

Fig. 1. Florida and Greater Antilles. Inset shows the locations of green turtle study sites (Tortuga Bay and Puerto Manglar) at Culebra, Puerto Rico (Map created using www.seaturtle.org/maptool)

is surrounded by white sandy beaches and rocky shores. The bottom is dominated by the seagrasses Syringodium filiforme and Halodule wrightii, or colonized by corals (Diez et al. 2010). Water depth and transparency are greater than in Puerto Manglar.

\section{Sampling methods}

Turtles were captured with a $200 \mathrm{~m}$ long and $5 \mathrm{~m}$ deep entangle net (no. 18 nylon twine, $25 \mathrm{~cm}$ stretch mesh) deployed for $1 \mathrm{~h}$ sets in areas $5 \mathrm{~m}$ deep or shallower with the help of a $7 \mathrm{~m}$ motor boat. Six swimmers snorkeled continually along the net to extract entangled turtles.

At Puerto Manglar, the entangle net was always set at the same location, enclosing the inner portion of the bay. At the wider Tortuga Bay, the net was set in 3 different locations: at the east side, west side, and center of the bay. Due to the $25 \mathrm{~cm}$ stretch mesh size of the net, turtles $<30 \mathrm{~cm}$ CCL could sometimes traverse the net without becoming entangled. Superior visibility at Tortuga Bay also allowed some small turtles to be captured by hand when encountered away from the net. All turtles captured were tagged on the front flippers with 2 external tags (inconel, and/or plastic tag), plus 1 passive integrated transponder (PIT) tag. Straight carapace length (SCL; from the nuchal notch to posterior-most tip) was measured to $0.1 \mathrm{~cm}$ using Haglof tree calipers. CCL was also mea- sured in a subset of turtles, using a fiberglass tape measure to the nearest $0.1 \mathrm{~cm}$. Body mass was measured with a Pesola spring scale. The presence of superficially visible fibropapilloma tumors was also noted. To reduce stress to the turtles, we kept them covered with wet towels and minimized handling time. Turtles were released near the location of capture.

The CMR program was conducted from 1997 to 2010, except for 1999. Capture sessions were performed twice a year at each site; during 'summer', i.e. May to October, and during 'winter', i.e. November to April, to account for any seasonality effect (noted by a slight change in water temperature from summer to winter, i.e. $\sim 3^{\circ} \mathrm{C}$ ). Due to rough weather conditions in 2008 and 2010, no sampling occurred during the summer season, and in 2002 and 2009, there was no sampling during the winter season. Each capture session lasted from 2 to $7 \mathrm{~d}$. In this analysis, we pooled the data per calendar year, since there was no evidence for inter-season differences for either of our study areas. Sampling effort was included in the size-class survival analysis, and it was defined by the number of net sets $\mathrm{yr}^{-1}$, which ranged from 5 to 16 , with an average of 12.6 net sets $\mathrm{yr}^{-1}$ for both sites.

\section{Data set and statistical modeling approach}

Our data comprises $273 \mathrm{CMR}$ individual history profiles. Green turtles were classified as juveniles if their CCL was $<65 \mathrm{~cm}$ at first capture, and as subadults if CCL ranged from 65 to $90 \mathrm{~cm}$ at first capture. This is an arbitrary classification because no study on the somatic growth and maturity stages is yet available for our aggregations. However, this classification or a similar one has been used previously (Chaloupka \& Limpus 2001, Bresette et al. 2010), and it serves the purpose of detecting the effect of different immature stages on survival rates.

CCL was estimated as a linear function of SCL measures. To obtain CCL, we estimated the correlation between SCL and CCL measurements of 39 individual turtles, for which we measured both lengths, and tested the significance of the correlation. From the slope of the curve we found the resulting linear equation, which was used to calculate the CCL for the remaining individuals.

During the 13 yr of CMR, we had only 2 dead recoveries in Culebra coastal waters and 10 reports 
of resights throughout the Greater Caribbean. Since the information on turtle fates was scarce, i.e. only $4.39 \%$ of the 273 individual turtles had a known fate after leaving our study areas, we proceeded with the analysis using a live-captures-only model. We used the CJS model according to Lebreton et al. (1992), implemented in the program MARK v6.1 (White \& Burnham 1999), to obtain maximum likelihood estimates of the size-class-specific survival and recapture probabilities for green turtles of Tortuga Bay and Puerto Manglar. This model was the best approach since it applies to live captures only and to open populations, i.e. those subjected to deaths, entries, and emigration (Schwarz \& Arnason 1996). Multiple tagging (i.e. flipper tags plus PIT tag) and photo identification of each captured turtle assured that throughout our CMR program we were able to correctly identify all recaptured individuals. Moreover, tag loss leaves easily identifiable scars on the flippers, so we are confident that no previously tagged individual was misidentified as a new capture. Therefore, we assumed that our data set fulfills the CJS assumption that no tags were lost. Furthermore, all turtles were released immediately after each capture event (CJS model assumptions can be found in Pollock et al. 1990). We assessed other assumptions of the CJS model, namely, homogeneity of recaptures and no effect of handling on survival (Pollock et al. 1990, Pledger et al. 2003) with goodness of fit (GoF) tests, which are detailed below. Both demographic heterogeneity, i.e. site and size class, and sampling effort variation were taken into account in GoF tests and in model selection.

One particular aspect of the CJS model is the fact that it confounds mortality and permanent emigration in the survival estimate in animals that permanently emigrate from a study area because they cease to be available for recapture and so appear to have died (Cormack 1993, Pradel et al. 1997, Bjorndal et al. 2003b). Although this aspect has the potential to underestimate the survival rate, it should not represent a problem if emigration rates are low (Chaloupka \& Limpus 2002). In our analysis, we estimated apparent survival probabilities, i.e. the probability that a turtle is alive and has not emigrated from our foraging aggregation. The other parameter estimated is the recapture probability, which is the probability that a turtle available for capture in the foraging aggregation is caught. Probabilities were estimated with the sin link function to enforce parameter values in the $[0,1]$ interval and to find correct estimates of the number of parameters expected (White \& Burnham 1999).

\section{GoF tests and model selection}

We used RELEASE in MARK to test the fit of 2 fullparameter CJS time-dependent models to our data. The models were: site- and time-specific survival and recapture probabilities, and size-class- and timespecific survival and recapture probabilities. Both models were analyzed by the following set of tests: TEST 2.C to verify the assumption of equal recapture probability (also known as the trap-test), TEST 3.SR to assess the effect of handling or of presumed transients on survival probability, TEST $2+3$, as a compilation of tests 2 and 3 to validate the fit of the global model to the data, and TEST 1 to look for differences in survival or recapture probabilities among groups (i.e. sites or size classes; Chaloupka \& Limpus 2005, Pradel et al. 2005). Additionally, we estimated the variance inflation factor, both employing the median test and RELEASE, as a measure of potential data overdispersion $(\hat{\mathrm{C}}>1)$. In the case of minor underdispersion ( $\hat{\mathrm{C}}$ slightly under 1 ), the value of $\hat{\mathrm{C}}$ was set to 1 (Anderson \& Burnham 2002).

After selecting the global CJS model that best fitted our data, we designed a number of reduced parameter models with biological meaning, to find the most parsimonious model that better explained our variance. We built models using parameter index matrices (PIMs), and we used the design matrix when sampling effort was added as a covariate. Reducing the number of parameters represents a tradeoff between more precise estimates with the elimination of potential artificial effects and model bias with underestimation of sampling variation (Burnham et al. 1995). Thus, deciding on the best model is critical for the interpretation of CMR data. The method for model selection was a second-order Akaike information criterion (AICc; Akaike 1973) to correct for small sample size. After selecting the best reduced parameter model, we used it to find maximum likelihood estimates of the size-class-specific survival and time-specific recapture probabilities, with the sin link function.

To investigate whether fibropapilloma disease influenced the survival of green turtles at our study sites, we analyzed the FP-specific survival probabilities, also using MARK. Since $>85 \%$ of the captured turtles with fibropapillomas were juveniles, and to avoid confounding FP and size-class effects, we only included the data corresponding to this size class. The CJS global model tested included the following groups: juvenile turtles that were always clean of tumors versus juvenile turtles that at least once were captured with visible fibropapillomas. We followed 
the procedure described above to test the GoF of the FP- and time-specific survival and recapture probabilities global model.

\section{RESULTS}

Our CMR data supported site fidelity of turtles to each foraging area (i.e. Puerto Manglar and Tortuga Bay); except for 1 individual, there was no migration between the 2 areas. Thus, each bay represents a distinct foraging ground with its unique aggregation of green turtles. From a total of 515 captures, 236 were at Tortuga Bay, which corresponded to 113 individual green turtles, and 279 were at Puerto Manglar, corresponding to 160 individuals.

Based on measurements of 39 individual green turtles, from which we had both CCL and SCL, we obtained the following regression equation to convert SCL to CCL in $\mathrm{cm}$ : CCL $=1.0737 \times \mathrm{SCL}-0.2897$; $\mathrm{R}^{2}=0.9994, \mathrm{p}=0.001$. CCL values ranged from 24.2 to $89.9 \mathrm{~cm}$. Adults, which we consider here as green turtles with a CCL $>90 \mathrm{~cm}$, were not captured in our study areas during the $13 \mathrm{yr}$ of our CMR program (Fig. 2). CCL (mean \pm SD) at first capture was $49.5 \pm$ $14.2 \mathrm{~cm}$ at Tortuga Bay, and $51.3 \pm 11.2 \mathrm{~cm}$ at Puerto Manglar. At Tortuga Bay, 81 \% of turtles were classified as juveniles and $19 \%$ as subadults, whereas at Puerto Manglar, there were $89 \%$ juveniles and $11 \%$ subadults. A $t$-test (2-tailed, type 3) indicated a significant difference in the CCL distribution of all cap-

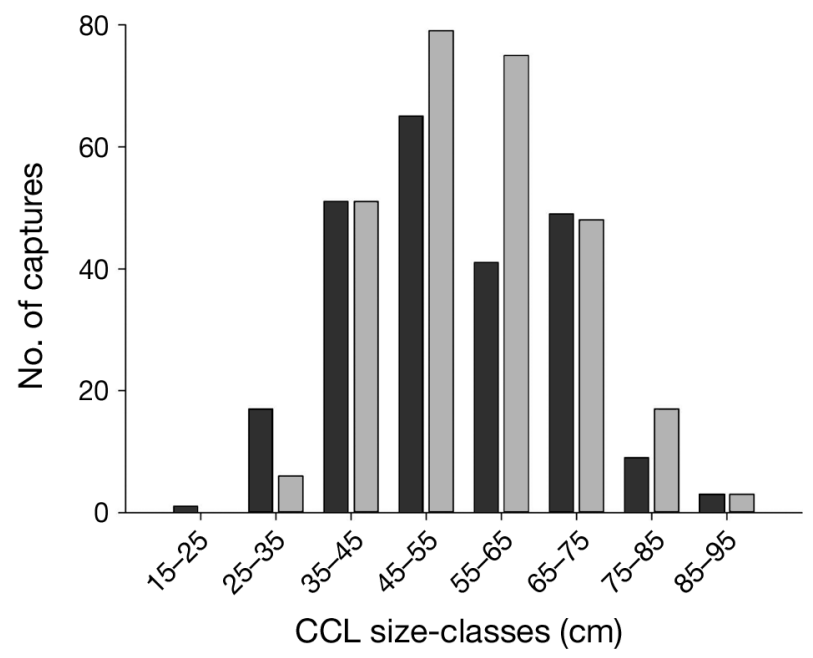

Fig. 2. Chelonia mydas. Curved carapace lengths (CCL) of all captured immature green turtles from 2 foraging areas in Puerto Rico. From a total of 515 captures, 236 were at Tortuga Bay (dark bars) and 279 at Puerto Manglar (light bars). All captures were made throughout $13 \mathrm{yr}$ of sampling (1997 to 2010) tures between the 2 foraging grounds ( $p=0.0465)$, with smaller juveniles at Tortuga Bay.

In general, turtles classified as juveniles had more recaptures, with $24 \%$ recaptured once, $18 \%$ recaptured twice, and $11 \%$ recaptured 3 or more times, up to 6 times. Subadults had considerably fewer recaptures, with $10 \%$ recaptured once and $8 \%$ recaptured 2 times (Fig. 3). No turtle classified as a subadult at first capture was caught more than twice.

\section{GoF tests and model selection}

The first global CJS model, viz. site- and time-specific survival and recapture probabilities, fitted the data well, with no evidence for nonconformity with the standard model assumptions (GoF TEST 2+3, p > 0.05). However, TEST 1 did not exhibit differences in survival or recapture probabilities among sites $\left(\chi_{0.05,23}^{2}=31.5691, p=0.1094 ;\right.$ summary of GoF results are presented in Table 1). We therefore pooled Tortuga Bay and Puerto Manglar CMR data sets and grouped individuals by size class (i.e. juveniles and subadults), to built the size-class- and timespecific survival and recapture probabilities CJS global model.

The new global CJS model fitted the data set well; both groups, juveniles and subadults, complied with the CJS assumptions (TEST $2+3$ for juveniles: $\chi_{0.05,33}^{2}=33.8648, \mathrm{p}=0.4256$; for subadults: $\chi_{0.05,5}^{2}=$ $0.7081, \mathrm{p}=0.9825)$. TEST 1 indicated a significant difference in survival probability between juveniles

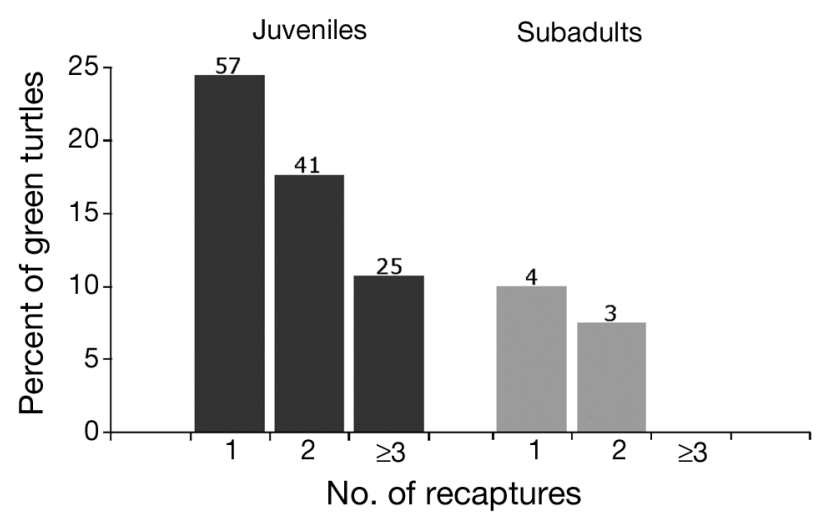

Fig. 3. Chelonia mydas. Percentage number of times that each turtle classified as a juvenile at first capture (curved carapace length, $\mathrm{CCL}<65 \mathrm{~cm}$ ) and each turtle classified as a subadult at first capture $(65 \mathrm{~cm}<\mathrm{CCL}<90 \mathrm{~cm})$ were recaptured, from both Puerto Manglar and Tortuga Bay foraging grounds, Puerto Rico. All captures were made between 1997 and 2010. Absolute numbers of turtles caught are above each column 


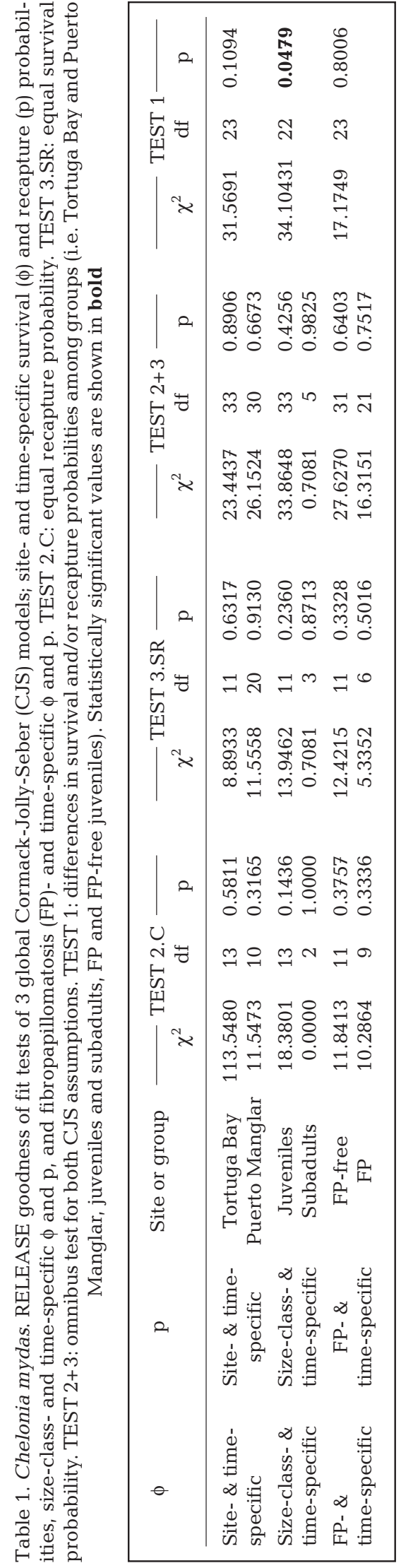

and subadults $\left(\chi_{0.05,22}^{2}=34.1043, \mathrm{p}=0.0479\right)$, so we analyzed GoF results separately for each group. The data set corresponding to all juveniles fulfilled the assumption of equal catchability (TEST 2.C, $\chi_{0.05,13}^{2}=18.3801, p=0.1436$ ). The results of TEST 3.SR complied with the assumption of equal survival probability of marked and non-marked individuals and showed no evidence for transients $\left(\chi_{0.05,11}^{2}=13.9462, p=0.2360\right)$. For the subadult group, the assumption of equal survival probability among marked and non-marked individuals was also fulfilled (TEST 3.SR, $\chi_{0.05,3}^{2}=0.7081, p=0.8713$ ). However, we could not obtain estimates of TEST 2.C for the subadult group, due to inadequate sample size. There was evidence for a slight underdispersion of the data, both with the median $\hat{\mathrm{c}}$ test, run with 10 replicates and 10 intermediate points $(\hat{\mathrm{c}}=$ $0.8767, \mathrm{CI}_{95 \%}=0.6882$ to 1.0651 ), and using RELEASE $\left(\hat{\mathrm{c}}=\chi^{2} / \mathrm{df}=0.9098\right)$. To run the subsequent models, $\hat{\mathrm{C}}$ was set to 1 .

Based on the GoF tests results, we assumed that the size-class- and time-specific survival and recapture probabilities global model was a good fit to our data set. We built 8 reduced parameter models, shown in Table 2, i.e. models that fitted the data well but required fewer parameters than the global CJS. When recapture probabilities were estimated as a linear function of sampling effort (model no. 2 in Table 2), and survival was size-class dependent, the AICc value was identical to the model with sizeclass-dependent survival and time-dependent recapture probability (model no. 1 in Table 2). Also there were no differences in parameter estimations between these 2 models. We continued our analysis with model no. 1, since adding sampling effort as a covariate did not make a difference in the analysis. Apparent survival and recapture probabilities of juvenile and subadult green turtles, from both study areas, were estimated using model no. 1 (sizedependent survival, time-dependent recapture probability).

\section{Survival and recapture probability estimates}

The apparent survival probability of juvenile green turtles was $0.8322\left(\mathrm{CI}_{95 \%}=0.7875\right.$ to 0.8690$)$, markedly higher than the estimate for subadult individuals, which was $0.5290\left(\mathrm{CI}_{95 \%}=0.3851\right.$ to 0.6682$)$. The recapture probabilities were not dependent on the size class but varied considerably through time, ranging from 0.0678 to 0.7301 , with an overall mean of $0.3594\left(\mathrm{CI}_{95 \%}=0.3109\right.$ to 0.4109$)$. 
Table 2. Chelonia mydas. Cormack-Jolly-Seber reduced parameter models built in MARK v6.1, for the Tortuga Bay and Puerto Manglar green turtle capture-mark-recapture data set from 1997 to 2010. No. par.: number of estimable parameters; AICc: corrected Akaike Information Criterion; Dev.: relative deviance. The best-fit model is shown in bold

\begin{tabular}{|c|c|c|c|c|c|c|}
\hline \multirow{2}{*}{ No. } & \multirow[b]{2}{*}{ MARK notation } & \multirow{2}{*}{$\begin{array}{l}\text { Model description } \\
\text { Survival probability }(\phi)\end{array}$} & \multirow[b]{2}{*}{ Recapture probability (p) } & \multirow{2}{*}{\multicolumn{2}{|c|}{ No. par. AICc }} & \multirow{2}{*}{ Dev. } \\
\hline & & & & & & \\
\hline 1 & $\{$ Phi(g) p(t) Sin PIM\} & Size-class specific & Time-specific & 14 & 1121.0359 & 344.5948 \\
\hline 2 & $\begin{array}{l}\{\text { Phi }(g) p(t . E F F O R T) \\
\text { Logit PIM }\}\end{array}$ & Size-class specific & $\begin{array}{l}\text { Linear function of sampling } \\
\text { effort and time-specific }\end{array}$ & 14 & 1121.0359 & 344.5948 \\
\hline 3 & $\{$ Phi $(g) p(g \times t)$ SinPIM $\}$ & Size-class specific & Size-class and time-specific & 26 & 1126.2780 & 323.6160 \\
\hline 4 & $\{$ Phi $(g \times t) p(t) \operatorname{Sin} P I M\}$ & Size-class and time-specific & Time-specific & 36 & 1132.0632 & 308.7948 \\
\hline 5 & Global model sin link & Size-class and time-specific & Size-class and time-specific & 46 & 1134.7580 & 287.5796 \\
\hline 6 & $\{$ Phi(t) p(t)Sin PIM $\}$ & Time-specific & Time-specific & 24 & 1137.2980 & 341.3220 \\
\hline 7 & $\{$ Phi $(g \times t) p(g)$ Sin PIM $\}$ & Size-class and time-specific & Size-class specific & 26 & 1161.4591 & 358.7971 \\
\hline 8 & $\{$ Phi(g) p(g) Sin PIM $\}$ & Size-class specific & Size-class specific & 4 & 1194.9696 & 439.3564 \\
\hline 9 & $\{$ Phi(.) p(.)Sin PIM\} & Constant & Constant & 2 & 1213.7864 & 462.2329 \\
\hline
\end{tabular}

\section{Effect of fibropapillomatosis on survival probability}

From the 515 total captures, $12 \%$ exhibited fibropapillomas, corresponding to 47 individual turtles. Of these, $32 \%$ were later recaptured clean of tumors, $8 \%$ were recaptured still holding tumors, and $60 \%$ were not seen again. In Puerto Manglar there was a higher prevalence of FP turtles than in Tortuga Bay, and the peak year for FP was 2003, with $33 \%$ of the total captures corresponding to afflicted animals (Fig. 4). No turtle $<40 \mathrm{~cm}$ CCL was caught or observed with external tumors. From the 47 individual turtles captured at least once with FP tumors, $85 \%$ were juveniles.

The FP- and time-specific global CJS model (using the data set for turtles within the juvenile size class only) fitted the data set well (TEST 2+3: turtles caught at least once with fibropapillomas: $\chi_{0.05,31}^{2}=$ $27.6270, \mathrm{p}=0.6403$; turtles always captured without signs of tumors: $\chi_{0.05,21}^{2}=16.3151, p=0.7517$ ). TEST 1 did not reveal a significant difference among the 2 groups $\left(\chi_{0.05,23}^{2}=17.1749, p=0.8006\right)$, so we did not proceed to estimate survival or recapture probabilities using this model (see Table 1 for GoF summary results).

\section{DISCUSSION}

We present the first analysis of survival probability for healthy and FP-afflicted green turtles in the West Indies, resulting from one of the longest ongoing mark-recapture programs of sea turtles.

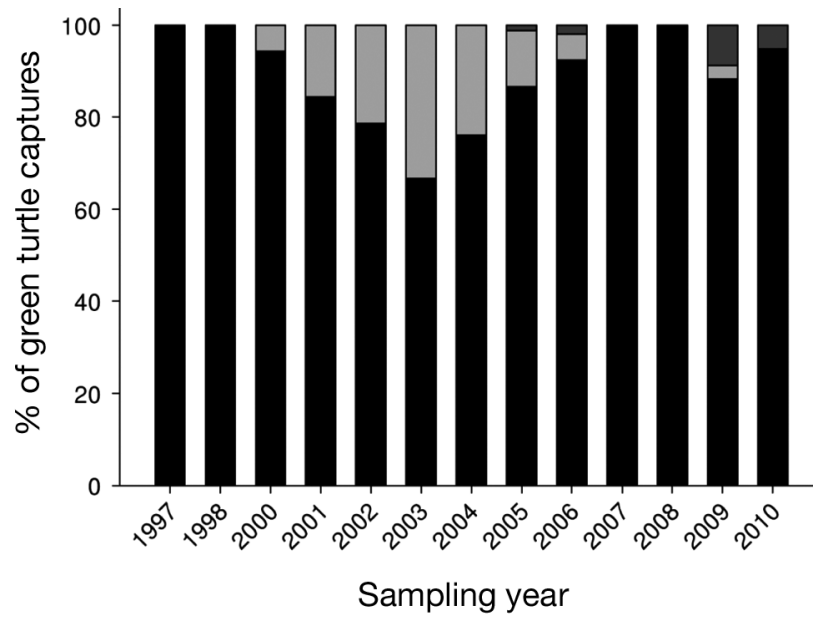

Fig. 4. Chelonia mydas. Captures $\mathrm{yr}^{-1}$ of green turtles during $13 \mathrm{yr}$ of capture-mark-recaptures, at 2 foraging areas from Culebra municipality, Puerto Rico. Black: percentage of captures of healthy individuals $(\mathrm{n}=452)$, from both Tortuga Bay and Puerto Manglar foraging grounds. Light grey: percentage of captures of green turtles with fibropapillomas (FP) at Puerto Manglar only ( $\mathrm{n}=55)$. Dark grey: percentage of captures of green turtles with FP from Tortuga Bay only $(n=7)$. No sampling occurred in 1999

\section{Culebra foraging grounds for smaller immatures}

Recapture profiles (Fig. 3) and CCL values (Fig. 2) show that large immatures are less frequently caught at our study areas. Additionally, GoF TEST 2.C indicates that the few recaptures of subadults are not a consequence of uneven recapture probabilities between size classes (Table 1), so our results indeed reflect the lack of larger turtles at Culebra foraging grounds. The CCL distributions appear to indicate that Tortuga Bay has smaller turtles than Puerto 
Manglar. However, this result could be biased since the clear water at Tortuga Bay allows capturing by hand small turtles that escape the entangle net, which would be missed at the turbid Puerto Manglar. At both foraging grounds, $>80 \%$ of marked turtles were classified as juveniles, and survival probabilities were not significantly different among sites.

The apparent survival probability differed significantly between size classes. Juveniles had a high apparent survival probability $\left(0.8322 ; \mathrm{CI}_{95} \%=0.7875\right.$ to 0.8690 ), comparable to that found for juvenile green turtles of a southern Great Barrier Reef (sGBR) population (Chaloupka \& Limpus 2005), comprising a mixture of both resident and transient turtles (Table 3). We assume that juveniles at our study sites are mainly residents, since our analysis revealed no evidence for transience (GoF 3.SR in Table 1). However, there could be a minor proportion of transients, undetected by the analysis, leading to a slight underestimation of the survival rate. Bjorndal et al. (2003a) used the Burnham model to estimate rates of true survival (S) and site fidelity (F) of green turtles at Union Creek bay, Bahamas. They calculated apparent survival as $\mathrm{S} \times \mathrm{F}$ (Bjorndal et al. 2003a). The apparent survival of juveniles from Culebra was similar to the apparent survival of smaller immatures from Union Creek, corresponding to cohorts 1 to 3 (Table 3, see Bjorndal et al. 2003b for cohort classification). In contrast, our survival estimate for juveniles was considerably higher than that for small imma- tures (SCL ranging from 22 to $64 \mathrm{~cm}$ ) from Conception Creek, Bahamas (Table 3; Bjorndal et al. 2003a). This probably results from the fact that at Conception Creek there is occasional poaching of turtles (Bjorndal et al. 2003a), which is not the case in Culebra.

The apparent survival probability of subadults was low $\left(0.5290 ; \mathrm{CI}_{95 \%}=0.3851\right.$ to 0.6682$)$, clearly inferior to the value for resident subadults of the sGBR population (Chaloupka \& Limpus 2005; Table 3). Instead, our estimation is closer to the apparent survival probability that Bjorndal et al. (2003a) found for a group of larger immatures at Union Creek, Bahamas, distinguished by increased emigration (cohort 4, Table 3).

Both mortality and permanent emigration may be lowering the survival estimate of green turtle subadults at Culebra foraging grounds. Our study sites and surrounding waters (i.e. the Green Turtle Critical Habitat limits defined by NOAA) are guarded by the Department of Natural and Environmental Resources of Puerto Rico, and no obvious human threats for sea turtle survival are known in these areas (e.g. poaching or by-catch). Nevertheless, an increased home range of larger immatures could potentially expose them to natural predation (e.g. sharks) or other hazards such as boat collisions that could be unnoticed. Conversely, recent studies have shown that larger immatures aggregate in deeper open waters, sometimes associated with adults, whereas smaller immatures show a preference for shallow protected bays (Seminoff et al. 2003, Koch et al. 2007, Bresette

Table 3. Chelonia mydas. Apparent survival $(\phi)$ and recapture (p) probabilities for different aggregations of green turtles from neritic habitats worldwide. Unless otherwise indicated, values in parentheses correspond to $95 \%$ confidence limits. CCL: curved carapace length; SCL: straight carapace length; sGBR: southern Great Barrier Reef, Australia; CJS: CormackJolly-Seber model; B: Burnham model

\begin{tabular}{|c|c|c|c|c|}
\hline Age class (size, cm) & Location & $\phi$ & $\mathrm{p}$ & Method \\
\hline Adult (CCL 85 to 120$)^{\mathrm{a}}$ & sGRB & $\begin{array}{c}0.9482 \\
(0.919 \text { to } 0.978)\end{array}$ & $\begin{array}{c}0.0799 \\
(0.042 \text { to } 0.118)\end{array}$ & CJS \\
\hline Subadult (CCL 65 to 90$)^{\mathrm{a}}$ & sGRB & $\begin{array}{c}0.8474 \\
(0.790 \text { to } 0.908)\end{array}$ & $\begin{array}{c}0.1695 \\
(0.049 \text { to } 0.449)\end{array}$ & CJS \\
\hline Juvenile (CCL 40 to 65$)^{\mathrm{a}}$ & sGRB & $\begin{array}{c}0.8804 \\
(0.835 \text { to } 0.927)\end{array}$ & $\begin{array}{c}0.2769 \\
(0.078 \text { to } 0.634)\end{array}$ & CJS \\
\hline Immature (SCL 25 to 84$)^{\mathrm{b}}$ & $\begin{array}{c}\text { Union Creek, } \\
\text { Bahamas }\end{array}$ & $\begin{array}{l}\text { 1: } 0.814,2: 0.752 \\
3: 0.776,4: 0.510^{d}\end{array}$ & $\begin{array}{c}0.549 \\
(0.262 \text { to } 0.884)^{\mathrm{e}}\end{array}$ & B \\
\hline Immature (SCL 22 to 64$)^{\mathrm{b}}$ & $\begin{array}{c}\text { Conception Creek, } \\
\text { Bahamas }\end{array}$ & $\begin{array}{c}0.680 \\
(0.631 \text { to } 0.725)\end{array}$ & $\begin{array}{c}0.590 \\
(0.328 \text { to } 0.940)^{\mathrm{e}}\end{array}$ & CJS \\
\hline Juvenile (CCL 24 to 65$)^{\mathrm{c}}$ & $\begin{array}{c}\text { Culebra, } \\
\text { Puerto Rico }\end{array}$ & $\begin{array}{c}0.8322 \\
(0.7875 \text { to } 0.8690)\end{array}$ & $\begin{array}{c}0.3594 \\
(0.3109 \text { to } 0.4109)\end{array}$ & CJS \\
\hline Subadult (CCL 65 to 90$)^{\mathrm{c}}$ & $\begin{array}{c}\text { Culebra, } \\
\text { Puerto Rico }\end{array}$ & $\begin{array}{c}0.5290 \\
\text { (0.3851 to } 0.6682)\end{array}$ & $\begin{array}{c}0.3594 \\
\text { (0.3109 to } 0.4109)\end{array}$ & CJS \\
\hline
\end{tabular}


et al. 2010). Moreover, the resight reports of 10 green turtles tagged at Culebra foraging areas, found at distant sites throughout the Greater Caribbean (i.e. Nicaragua, Venezuela, Colombia, and Brazil), indicate that at least some individuals are emigrating from Puerto Manglar and Tortuga Bay. Although mortality cannot be disregarded as a factor influencing the survival estimate for the larger immatures, we understand that permanent emigration is the main cause for the low rate. Hence, we recommend caution when interpreting the survival estimates of these individuals, since emigration is biasing the estimate. Home range studies (Seminoff et al. 2002, Makowski et al. 2006) and expansion of our sampling areas to open waters surrounding our study sites could elucidate whether larger immatures, similar to other areas in Florida and Mexico (Seminoff et al. 2003, Koch et al. 2007, Bresette et al. 2010), are changing from a more sheltered habitat to deeper and more exposed areas. Finally, the survival estimate of green turtles in the juvenile size class should be close to their true survival due to the resident behavior of this class, which is a valuable vital rate to use in population viability analysis.

\section{No effect of FP on apparent survival probability}

Our results revealed no significant differences in the apparent survival or recapture probabilities among juvenile turtles always captured clean of fibropapillomas versus those captured at least once with visible tumors. This means that juvenile turtles with FP do not exhibit increased mortality or increased emigration rates at our study sites. In addition, one-third of the turtles caught at least once with visible tumors were later recaptured, completely recovered. Different levels of prevalence and pathology have been reported among distinct geographic areas (Herbst et al. 1995, Herbst \& Klein 1995, Aguirre et al. 1998, Ene et al. 2005). Whether this variance results from particular environmental factors or from different levels of virulence, associated with virus variants, is an ongoing discussion (Greenblatt et al. 2005). Thus far, it appears that FP has had little impact on the aggregations of green turtles from Tortuga Bay and Puerto Manglar.

\section{CONCLUSION}

Estimating vital rates is difficult for numerous species, especially for long-lived marine vertebrates, due to a paucity of data (Bradshaw et al. 2007). Survival probability analysis from live recaptures, although limited due to the confounding effect of mortality and permanent emigration, is still a powerful tool to assess population dynamics of markrecaptured animals when only live captures are available. Moreover, if emigration rate is low, it allows setting the lower limit for the survival of a given subpopulation. Sharks and other large pelagic vertebrates, such as the Atlantic bluefin tuna, also depend on inshore areas, used mainly as nurseries, for their development (Fromentin \& Powers 2005, Duncan \& Holland 2006). While in the open sea, overfishing and incidental capture are constant threats, difficult to control, inshore areas offer more opportunities for conducting CMR programs, allowing estimating survival rates, to detect population trends and to apply in population viability analysis.

Lastly, we highlight the importance of Tortuga Bay and Puerto Manglar for green turtles and the need to protect them. Culebra Island is currently under strong pressure for development, which may jeopardize the existence of natural habitats for wildlife. And although development is absent at Tortuga Bay, it is a hot spot for recreational boaters, and it is not uncommon to see them anchor on the seagrass beds. Reinforcement of laws for the protection of these areas should be considered, specifically concerning urban development around Puerto Manglar and recreational tourism.

Acknowledgements. The long-term study at Culebra was achieved thanks to the help of numerous field assistants and volunteers. We especially thank A. Alvarez; C. Carrion, N. Jimenez, G. Olivera, R. Soler, and Y. Vargas. Research support was provided by the Department of Natural and Environmental Resources of Puerto Rico (DNER), US National Marine Fisheries Service (NMFS-NOAA, Section 6, grant no. NA08NMF4720436), US Fish and Wildlife Service, Sociedad Chelonia, and WIDECAST. Work was conducted under permits by NMFS-NOAA (permit nos. 1253 and 151801) and DNER (06-EPE-016).

\section{LITERATURE CITED}

Aguirre AA, Spraker TR, Balazs GH, Zimmerman B (1998) Spirorchidiasis and fibropapillomatosis in green turtles from the Hawaiian Islands. J Wildl Dis 34:91-98

Akaike H (1973) Information theory and an extension of the maximum likelihood principle. In: Petrov BN, Csàki F (eds) 2nd Int Symp Inf Theory. Akademiai Kiàdo, Budapest, p 267-281

Anderson DR, Burnham KP (2002) Avoiding pitfalls when using information-theoretic methods. J Wildl Manag 66: 912-918

Arthur K (2008) A comparison of immature green turtles 
(Chelonia mydas) diets among seven sites in the main Hawaiian Islands. Pac Sci 62:205-217

Barker RJ (1997) Joint modeling of live-recapture, tagresight, and tag-recovery data. Biometrics 53:666-677

$>$ Baum JK, Myers RA, Kehler DG, Worm B, Harley SJ, Doherty PA (2003) Collapse and conservation of shark populations in the northwest Atlantic. Science 299: 389-392

Bjorndal KA (1997) Foraging ecology and nutrition of sea turtles. In: Lutz PL, Musick JA (eds) The biology of sea turtles, Vol 1. CRC Press, Boca Raton, FL, p 199-231

Bjorndal KA, Bolten AB, Chaloupka MY (2003a) Survival probability estimates for immature green turtles Chelonia mydas in the Bahamas. Mar Ecol Prog Ser 252: 273-281

Bjorndal KA, Bolten AB, Martins HR (2003b) Estimates of survival probabilities for oceanic-stage loggerhead sea turtles (Caretta caretta) in the North Atlantic. Fish Bull 101:732-736

> Bjorndal KA, Bolten AB, Chaloupka MY (2005) Evaluating trends in abundance of immature green turtles, Chelonia mydas, in the Greater Caribbean. Ecol Appl 15: 304-314

Bolten AB (2003) Variation in sea turtle life history patterns: neritic versus oceanic developmental stages. In: Lutz PL, Musick JA, Wyneken J (eds) The biology of sea turtles, Book 2. CRC Press, Boca Raton, FL, p 243-257

> Bowen BW, Karl SA (2007) Population genetics and phylogeography of sea turtles. Mol Ecol 16:4886-4907

> Bradshaw CJA, Mollet HF, Meekan MG (2007) Inferring population trends for the world's largest fish from mark-recapture estimates of survival. J Anim Ecol 76: 480-489

Bresette MJ, Witherington BE, Herren RM, Bagley DA and others (2010) Size-class partitioning and herding in a foraging group of green turtles Chelonia mydas. Endang Species Res 9:105-116

Burnham KP (1993) A theory for combined analysis of ring recovery and recapture data. In: Lebreton JD, North PM (eds) Marked individuals in the study of bird population dynamics. Birkhäuser Verlag, Basel, p 199-213

Burnham KP, Anderson DR, White GC (1995) Selection among open population capture-recapture models when capture probabilities are heterogeneous. J Appl Stat 22: 611-624

> Campbell CL, Lagueux CJ (2005) Survival probability estimates for large juvenile and adult green turtles (Chelonia mydas) exposed to an artisanal marine turtle fishery in the Western Caribbean. Herpetologica 61:91-103

Carr A, Carr MH, Meylan AB (1978) The ecology and migrations of sea turtles. 7. The West Caribbean green turtle colony. Bull Am Mus Nat Hist 162:1-46

> Castro JI (1993) The shark nursery of Bulls Bay, South Carolina, with a review of the shark nurseries of the southeastern coast of the United States. Environ Biol Fishes 38: $37-48$

> Chaloupka M, Balazs G (2007) Using Bayesian state-space modelling to assess the recovery and harvest potential of the Hawaiian green sea turtle stock. Ecol Model 205: 93-109

> Chaloupka M, Limpus C (2001) Trends in the abundance of sea turtles resident in southern Great Barrier Reef waters. Biol Conserv 102:235-249

> Chaloupka M, Limpus CJ (2002) Survival probability estimates for the endangered loggerhead sea turtle resident in southern Great Barrier Reef waters. Mar Biol 140: 267-277

Chaloupka M, Limpus C (2005) Estimates of sex- and ageclass-specific survival probabilities for a southern Great Barrier Reef green sea turtle population. Mar Biol 146: 1251-1261

Chaloupka M, Limpus C, Miller J (2004) Green turtle somatic growth dynamics in a spatially disjunct Great Barrier Reef metapopulation. Coral Reefs 23:325-335

Chaloupka M, Bjorndal KA, Balazs GH, Bolten AB and others (2008) Encouraging outlook for recovery of a once severely exploited marine megaherbivore. Glob Ecol Biogeogr 17:297-304

> Cormack RM (1993) Variances of mark-recapture estimates. Biometrics 49:1188-1193

Crouse DT (1999) The consequences of delayed maturity in a human-dominated world. Am Fish Soc Symp 23: 195-202

- Crouse DT, Crowder LB, Caswell H (1987) A stage-based population model for loggerhead sea turtles and implications for conservation. Ecology 68:1412-1423

Diez CE, van Dam RP, Velez-Zuazo X, Torres F, Scharer M, Molina M (2010) Habitat and population assessment of Caribbean green turtle aggregations inhabiting the Culebra Archipelago's coastal waters. In: Dean K, LopezCastro MC (comps) Proc 28th Annu Symp Sea Turtle Biol Conserv. NOAA Tech Memo NOAA NMFS-SEFSC. US Department of Commerce, Miami, FL, p 272

> Duncan KM, Holland KN (2006) Habitat use, growth rates and dispersal patterns of juvenile scalloped hammerhead sharks Sphyrna lewini in a nursery habitat. Mar Ecol Prog Ser 312:211-221

> Eguchi T, Seminoff JA, LeRoux RA, Dutton PH, Dutton DL (2010) Abundance and survival rates of green turtles in an urban environment: coexistence of humans and an endangered species. Mar Biol 157:1869-1877

- Ene A, Su M, Lemaire S, Rose C and others (2005) Distribution of chelonid fibropapillomatosis-associated herpesvirus variants in Florida: molecular genetic evidence for infection of turtles following recruitment to neritic developmental habitats. J Wildl Dis 41:489-497

Epperly SP, Braun-McNeill J, Richards PM (2007) Trends in catch rates of sea turtles in North Carolina, USA. Endang Species Res 3:283-293

Fromentin JM, Powers JE (2005) Atlantic bluefin tuna: population dynamics, ecology, fisheries and management. Fish Fish 6:281-306

Fujiwara M, Caswell H (2002) Estimating population projection matrices from multi-stage mark-recapture data. Ecology 83:3257-3265

Gillanders BM, Able KW, Brown JA, Eggleston DB, Sheridan PF (2003) Evidence of connectivity between juvenile and adult habitats for mobile marine fauna: an important component of nurseries. Mar Ecol Prog Ser 247:281-295

- Greenblatt RJ, Work TM, Dutton P, Sutton CA and others (2005) Geographic variation in marine turtle fibropapillomatosis. J Zoo Wildl Med 36:527-530

Heppell SS (1998) Application of life-history theory and population model analysis to turtle conservation. Copeia 367-375

Heppell SS, Snover ML, Crowder LB (2003) Sea turtle population ecology. In: Lutz PL, Musick JA, Wyneken J (eds) The biology of sea turtles, Book 2. CRC Press, Boca Raton, FL, p 275-306 
Herbst LH, Klein PA (1995) Green turtle fibropapillomatosis - challenges to assessing the role of environmental cofactors. Environ Health Perspect 103(Suppl 4):27-30

Herbst LH, Jacobson ER, Moretti R, Brown T, Sundberg JP, Klein PA (1995) Experimental transmission of green turtle fibropapillomatosis using cell-free tumor extracts. Dis Aquat Org 22:1-12

Herbst L, Ene A, Su M, Desalle R, Lenz J (2004) Tumor outbreaks in marine turtles are not due to recent herpesvirus mutations. Curr Biol 14:R697-R699

IUCN (2011) IUCN Red List of Threatened Species. Version 2011.1. http://www.iucnredlist.org/. Downloaded on 14 October 2011

Jackson JBC, Kirby MX, Berger WH, Bjorndal KA and others (2001) Historical overfishing and the recent collapse of coastal ecosystems. Science 293:629-637

Koch V, Brooks LB, Nichols WJ (2007) Population ecology of the green/black turtle (Chelonia mydas) in Bahia Magdalena, Mexico. Mar Biol 153:35-46

Lebreton JD, Burnham KP, Clobert J, Anderson DR (1992) Modeling survival and testing biological hypothesis using marked animals - a unified approach with case studies. Ecol Monogr 62:67-118

Lewison RL, Crowder LB, Read AJ, Freeman SA (2004) Understanding impacts of fisheries bycatch on marine megafauna. Trends Ecol Evol 19:598-604

Lotze HK, Lenihan HS, Bourque BJ, Bradbury RH and others (2006) Depletion, degradation, and recovery potential of estuaries and coastal seas. Science 312:1806-1809

Makowski C, Seminoff JA, Salmon M (2006) Home range and habitat use of juvenile Atlantic green turtles (Chelonia mydas L.) on shallow reef habitats in Palm Beach, Florida, USA. Mar Biol 148:1167-1179

Monticelli D, Ceia R, Heleno R, Laborda H and others (2010) High survival rate of a critically endangered species, the Azores bullfinch Pyrrhula murina, as a contribution to population recovery. J Ornithol 151:627-636

Pledger S, Pollock KH, Norris JL (2003) Open capturerecapture models with heterogeneity: I. Cormack-JollySeber model. Biometrics 59:786-794

Pollock KH, Nichols JD, Brownie C, Hines JE (1990) Statistical inference for capture-recapture experiments. Wildl Monogr 107:1-97

Editorial responsibility: Matthias Seaman, Oldendorf/Luhe, Germany
Powles H, Bradford MJ, Bradford RG, Doubleday WG, Innes S, Levings CD (2000) Assessing and protecting endangered marine species. ICES J Mar Sci 57:669-676

Pradel R, Hines JE, Lebreton JD, Nichols JD (1997) Capture-recapture survival models taking account of transients. Biometrics 53:60-72

Pradel R, Gimenez O, Lebreton JD (2005) Principles and interest of GOF tests for multistate capture-recapture models. Anim Biodivers Conserv 28:189-204

> Schwarz CJ, Arnason AN (1996) A general methodology for the analysis of capture-recapture experiments in open populations. Biometrics 52:860-873

Seminoff JA, Resendiz A, Nichols WJ (2002) Home range of green turtles Chelonia mydas at a coastal foraging area in the Gulf of California, Mexico. Mar Ecol Prog Ser 242: 253-265

Seminoff JA, Jones TT, Resendiz A, Nichols WJ, Chaloupka MY (2003) Monitoring green turtles (Chelonia mydas) at a coastal foraging area in Baja California, Mexico: multiple indices to describe population status. J Mar Biol Assoc UK 83:1355-1362

Soykan CU, Moore JE, Zydelis R, Crowder LB, Safina C, Lewison RL (2008) Why study bycatch? An introduction to the theme section on fisheries bycatch. Endang Species Res 5:91-102

Varghese SP, Varghese S, Somvanshi VS (2010) Impact of tuna longline fishery on the sea turtles of Indian seas. Curr Sci 98:1378-1384

Velez-Zuazo X, Diez CE, van Dam RP, Torres-Velez F (2010) Genetic structure and origin of a juvenile aggregation affected by fibropapillomatosis: potential impact on adult recruitment. In: Dean K, Lopez-Castro MC (comps) Proc 28th Annu Symp Sea Turtle Biol Conserv. NOAA Tech Memo NOAA NMFS-SEFSC. US Department of Commerce, Miami, FL, p 272

- Wallace BP, DiMatteo AD, Hurley BJ, Finkbeiner EM and others (2010) Regional management units for marine turtles: a novel framework for prioritizing conservation and research across multiple scales. PLoS ONE 5:e15465

White GC, Burnham KP (1999) Program MARK: survival estimation from populations of marked animals. Bird Study 46:120-139

Submitted: March 1, 2011; Accepted: August 5, 2011 Proofs received from author(s): October 16, 2011 